medRxiv preprint doi: https://doi.org/10.1101/2022.03.02.22271664; this version posted March 4, 2022. The copyright holder for this preprint (which was not certified by peer review) is the author/funder, who has granted medRxiv a license to display the preprint in perpetuity.

It is made available under a CC-BY-NC-ND 4.0 International license .

\title{
1 Serum levels of the novel adipokine isthmin-1 are associated with obesity in pubertal
} 2 boys

3 Francisco Javier Ruiz-Ojeda ${ }^{1,2^{*}}$, Augusto Anguita-Ruiz ${ }^{1,2,3,4,5}$, Maria C. Rico ${ }^{1}$, Rosaura Leis ${ }^{5,6,7,8}$, 4 Gloria Bueno $5,9,10$, Mercedes Gil-Campos ${ }^{4,11}$, Ángel Gil ${ }^{1,2,3,5}$, Concepción M Aguilera ${ }^{1,2,3,5^{*}}$

5
${ }^{1}$ Department of Biochemistry and Molecular Biology II, School of Pharmacy, University of Granada, Spain

2 Instituto de Investigación Biosanitaria ibs.GRANADA, 18012 Granada, Spain

${ }^{3}$ Institute of Nutrition and Food Technology "José Mataix", Center of Biomedical Research, University of Granada, Avda. del Conocimiento s/n. 18016 Armilla, Granada, Spain

${ }^{4}$ Barcelona Institute for Global Health, ISGlobal, 08003 Barcelona, Spain

${ }^{5}$ CIBEROBN, (Physiopathology of Obesity and Nutrition CB12/03/30038), Institute of Health Carlos III (ISCIII), Madrid 28029, Spain

${ }^{6}$ Unit of Investigation in Human Nutrition, Growth and Development of Galicia (GALINUT), University of Santiago de Compostela (USC), Santiago de Compostela, Spain

${ }^{7}$ Pediatric Nutrition Research Group. Institute of Sanitary Research of Santiago de Compostela (IDIS). CHUS-USC. 15706 Santiago de Compostela, Spain

${ }^{8}$ Unit of Pediatric Gastroenterology, Hepatology and Nutrition. Pediatric Service. University Clinical Hospital of Santiago (CHUS). 15706 Santiago de Compostela, Spain ${ }^{9}$ GENUD Research group, University of Zaragoza, Institute of Sanitary Research of Aragón (IIS Aragón), Zaragoza, Spain

${ }^{10}$ Agri-food Institute of Aragon (IA2), Zaragoza, Spain

${ }^{11}$ Unit of Pediatric Endocrinology, University Clinical Hospital Lozano Blesa, 50009 Zaragoza, Spain (G.B.) Metabolism and Investigation Unit, Reina Sofia University Hospital, Maimónides. Institute of Biomedicine Research of Córdoba (IMIBIC), University of Córdoba, 14071 Córdoba, Spain

${ }^{*}$ Corresponding Authors:

Francisco Javier Ruiz-Ojeda/Concepción Aguilera

Department of Biochemistry and Molecular Biology II, School of Pharmacy, University of Granada, Spain. Telephone: +34 626552847. E-mail: fruizojeda@ugr.es/caguiler@ugr.es 
medRxiv preprint doi: https://doi.org/10.1101/2022.03.02.22271664; this version posted March 4, 2022. The copyright holder for this preprint (which was not certified by peer review) is the author/funder, who has granted medRxiv a license to display the preprint in perpetuity.

It is made available under a CC-BY-NC-ND 4.0 International license .

\section{Abstract}

Purpose: The aims of this study were; 1 ) to evaluate if there is an association between the serum levels of the novel insulin-like adipokine isthmin-1 (ISM1) and obesity-related phenotypes in a population of Spanish children, 2) to investigate the plausible molecular alterations behind the alteration of the serum levels of this protein in children with obesity.

Methods: The study population is a sub-cohort of the PUBMEP research project, consisting of a cross-sectional population of 119 pubertal children with overweight (17 boys, 19 girls), obesity (20 boys, 25 girls) and normal weight (17 boys, 21 girls). All subjects were classified into experimental groups according to their sex, obesity and insulin resistance (IR) status. They counted on anthropometry, glucose, and lipid metabolism, inflammation and cardiovascular biomarkers as well as ISM1 serum levels measured. This population was intended as a discovery population in which to elucidate the relationship between obesity and ISM1 levels in children. Furthermore, the study population had blood whole-genome DNA methylation allowing deepening into the obesityISM1 molecular relationship.

Results: Higher serum levels of ISM1 were observed in boys with obesity when compared with normal-weight $(P=0.004)$, and overweight $(P=0.007)$. ISM1 serum levels were positively associated with BMI $Z$-score $(P=0.005)$, and negatively with myeloperoxidase (MPO) $(p=0.043)$ in boys. Nevertheless, we did not find associations between ISM1 serum levels and metabolic outcomes in girls, indicating a putative sexual dimorphism. DNA methylation levels in twolevels of ISM1 in children.

Discussion: We report an unprecedented study that provides a major step forward showing that ISM1 is robustly associated with obesity in pubertal boys, elucidating how this protein might be of special relevance as a new biomarker of obesity in children.

Keywords: isthmin-1, obesity, children, puberty, epigenetics

\section{Implications and Contribution}

Study findings reveal differences in the circulating levels of the novel insulin-like adipokine ISM1 between pubertal children with obesity and normal-weight, and different associations with metabolic traits, which may be further investigated to be used as a potential biomarker of obesity in young populations. 
medRxiv preprint doi: https://doi.org/10.1101/2022.03.02.22271664; this version posted March 4, 2022. The copyright holder for this preprint (which was not certified by peer review) is the author/funder, who has granted medRxiv a license to display the preprint in perpetuity. It is made available under a CC-BY-NC-ND 4.0 International license .

71 Childhood obesity is increasing globally and total adiposity is the key driver of metabolic risk in

72 children and adolescent, which represent a strong risk factor for insulin resistance (IR) and future

73 type 2 diabetes (T2D) [1]. Puberty is a time of metabolic and hormonal changes, and it is

74 associated with a reduced insulin sensitivity that recovers at puberty completion in only some 75 children [2-4]. In growing children, adipocyte hypertrophy is associated with inflammation and 76 local and systemic IR, independently of BMI and fat mass, being adipose tissue essential to 77 maintain a functional metabolism [5]. However, the molecular mechanism of IR is still unknown, 78 particularly in children. This is in part because processes such as growth and puberty affect insulin 79 secretion and sensitivity [6]. Hence, understanding the molecular and biological processes 80 underlying metabolic changes (glucose and lipid regulation) during puberty, and identifying 81 pathways and biomarkers that might help to increase peripheral glucose uptake would be 82 beneficial to reduce the impact of obesity and to prevent T2D. A recent paper reported that the 83 protein isthmin-1 (ISM1) is secreted by mature adipocytes and triggers a signaling cascade similar 84 to that of insulin. The novel adipokine acts through a unidentified receptor tyrosine kinase and, at 85 pharmacological doses in mice, ISM1 ameliorates metabolic disturbances associated with T2D, 86 including hyperglycemia and liver steatosis [7, 8]. Here, we report that serum levels of the novel 87 insulin-like adipokine ISM1 is, indeed, associated with obesity in pubertal boys, but not in girls in a well-characterized population of Spanish children under a cross-sectional design. Furthermore, we identified DNA methylation in two-enhancer-related CpG sites of the ISM1 region (cg14269097 and cg14269097) associated with serum levels of ISM1 in children with obesity.

\section{Methods}

92 This study was conducted within the context of the multicenter PUBMEP study in Spain "Puberty and metabolic risk in children with obesity", previously published [9, 10]. Here, a sub-population of 119 pubertal children (54 boys and 65 girls) from the whole PUBMEP cohort was selected for analysis. A total of 38 were normal-weight (17 boys), 36 overweight (17 boys) and 45 children with obesity (20 boys). The following characteristics were considered as exclusion criteria: birth weight <2500 g; intake of any drug that could alter blood glucose, blood pressure or lipid metabolism; not being able to comply with the study procedures and being participating or having participated in the last three months in an investigation project. This study was conducted according to the guidelines set out in the Declaration of Helsinki (Edinburgh 2000 revised), and all procedures were approved by the Ethics and Research Committee of Galicia Autonomous Community (2011/198 and 2016/522). Written consent was obtained from the parents of all the 
medRxiv preprint doi: https://doi.org/10.1101/2022.03.02.22271664; this version posted March 4, 2022. The copyright holder for this preprint (which was not certified by peer review) is the author/funder, who has granted medRxiv a license to display the preprint in perpetuity. It is made available under a CC-BY-NC-ND 4.0 International license .

(cm) and waist circumference (WC) (cm) were measured using standardized procedures. BMI zscore was calculated based on the Spanish reference standards published. Blood pressure was measured three times for each individual by the same examiner using a mercury sphygmomanometer and following international recommendations [11]. Measures of lipid and glucose metabolism, hormones and classical biochemical parameters were performed at the laboratories of each participating hospital following internationally accepted quality control protocols. Blood samples were collected in overnight fasting conditions, centrifuged, and plasma and serum were stored at $-80^{\circ} \mathrm{C}$. The presence of IR in children was defined according to the HOMA insulin resistance (HOMA-IR) index. The cut-off points were obtained from a previously well-described Spanish cohort composed of children and adolescents [12,13]. The cut-off points for IR were based on the $95^{\text {th }}$ HOMA-IR percentile, considering sex (HOMA-IR $\geq 3.38$ in boys and HOMA-IR $\geq 3.90$ in girls). These cut-off points have already been tested and validated as good metabolic risk classifiers in our population according to the results from a previous PUBMEP report [10]. Plasma adipokines, inflammation, and cardiovascular risk biomarkers (adiponectin, leptin, resistin, tumor necrosis factor alpha (TNF- $\alpha$ ), high-sensitivity CRP (hsCRP), interleukin (IL)-6, IL-8, total plasminogen activator inhibitor-1 (PAI-1), P-selectin, myeloperoxidase (MPO), monocyte chemoattractant protein 1 (MCP-1), soluble intercellular cell adhesion molecule-1 sICAM-1, and soluble vascular cell adhesion molecule-1 (sVCAM)) were analyzed in all samples and time points using XMap technology (Luminex Corporation, Austin, TX) and human monoclonal antibodies (Milliplex Map Kit; Millipore, Billerica, MA) as previously reported [10, 14]. Descriptive data are expressed as mean (standard deviation) or median [min-max] if not normally distributed. One-way ANOVA, Kruskal-Wallis and the Welch test were employed to assess group differences. DNA methylation analysis was carried out by using the Infinium MethylationEPIC microarray using bead chip technology (Illumina, San Diego, CA, USA) as previously described [10]. ISM1 protein levels were determined in serum using the Human SEQ515Hu for ISM 1 (Cloud-Clone Corp., USA), an enzyme-linked immune-absorbent assay kit according to the manufacturers' instructions. The coefficient of variance was 4\%. Two-way ANOVA and Tukey's multiple comparisons test were employed to assess groups' differences in ISM1 levels between boys and girls and normal-weight, overweight and obese children. Multiple linear regression (MLR) analyses were applied for all continuous variables to study their association with ISM1 levels. In these analyses, origin, age, gender, pubertal stage, height, BMI Z-score, and insulin were adjusted as confounders when necessary. A P-value $<0.05$ was considered as significant. Given the number of analyzed outcomes, we considered false discovery rate (FDR) as in Benjamini and Hochberg to correct for multiple hypothesis testing. MLRs were also applied for all 
medRxiv preprint doi: https://doi.org/10.1101/2022.03.02.22271664; this version posted March 4, 2022. The copyright holder for this preprint (which was not certified by peer review) is the author/funder, who has granted medRxiv a license to display the preprint in perpetuity.

It is made available under a CC-BY-NC-ND 4.0 International license .

calculated deltas to study their correlation with the change in ISM1 levels. All described analyses were performed in R environment version 3.6.0.

\section{Results}

General characteristics of the 119 children in this cross-sectional study are shown in Supplementary Table 1. ISM1 serum levels according to obesity by sex are shown in Fig. 1A. Higher ISM1 serum levels were observed in boys with obesity when compared with normal-weight $(P=0.0037)$ and overweight $(P=0.0071)$, non-adjusted. However, no changes were observed in girls. When all subjects of the sample were compared together, we found higher levels in children with obesity compared with those with normal weight $(P=0.0413)$ and with those overweight $(P$ $=0.0102)$. A trend to increase the ISM1 levels in boys with IR was observed, but no statistical differences were shown between normal-weight non-IR, non-IR and IR children (Fig. 1B).

To elucidate the relationship between ISM1 and obesity, MLRs were further conducted in a wide range of metabolic outcomes separated by sex (Tables 1-2) and properly adjusted by confounders such as age, origin, height, BMI and IR when applicable. In boys, the strongest association was found for BMl Z-score $(P=0.005)$, but not in girls (Fig. 2A and S1A). MPO $(P=0.043)$ was negatively associated with ISM1 serum levels in boys. All of them were properly adjusted for confounders (please, see Table 1 and 2 legends), both in boys and girls. Surprisingly, though both ISM1 and leptin levels are significantly higher in children with obesity, no significant associations were identified with leptin neither in boys nor in girls (Fig. 2B).

Fifty-one methylation sites were selected from the Infinium Methylation EPIC microarray of which two were annotated as promoter-associated CpGs (Supplementary Table 2). All the CpGs were annotated as open sea. We found a positive significant association between the methylation status of the probe cg03304641 and ISM1 serum levels in pubertal children ( $P=0.0062)$ (Fig. 3A, S2A and Supplementary Table 2). However, for the probe cg14269097 there was a negative association with ISM1 serum levels ( $\mathrm{P}=0.038)$ (Fig. 3B, S2B and Supplementary Table 2).

\section{Discussion}

In the present work, we show higher serum levels of the novel insulin-like adipokine ISM1 in pubertal children with obesity, with a strong association with BMI Z-score in boys. Moreover, ISM1 was also associated with MPO, an enzyme associated with IR and inflammation in individuals with overweight [15]. These findings illustrate how this protein might be of special relevance as a new biomarker of obesity in children.

In obesity, hypertrophic adipocytes and adipose tissue-resident immune cells accelerate a lowgrade and chronic, proinflammatory profile with altered secretion of adipokines and lipokines, 
medRxiv preprint doi: https://doi.org/10.1101/2022.03.02.22271664; this version posted March 4, 2022. The copyright holder for this preprint (which was not certified by peer review) is the author/funder, who has granted medRxiv a license to display the preprint in perpetuity. It is made available under a CC-BY-NC-ND 4.0 International license .

171 thereby exacerbating cardiometabolic disease [16]. In this context, the production and secretion

172 of adipokines and lipokines, which contribute to systemic energy metabolism by different 173 mechanisms, are dependent on the energy status of adipose tissue. Hence, further preclinical 174 and clinical studies exhibiting the activation or inhibiting the signaling of specific adipokines or 175 lipokines (e.g. by using adipokine-neutralizing antibodies) may be an approach suitable to treat 176 or prevent the development of metabolic disease. Nevertheless, efficacy and safety in humans 177 need to be confirmed [17]. ISM1 is a secreted protein, originally discovered in fetal brain 178 development and expressed in the brain, lung, vasculature, skin and immune cells [18]. ISM1 has 179 been recently identified in mouse and human adipocytes, regulating glucose uptake while 180 suppressing hepatic lipid synthesis, thus improving hyperglycemia and reducing lipid accumulation in mouse models. Besides, circulating plasma levels of human ISM1 has been detected at an average of $50 \mathrm{pg} / \mathrm{mL}$ and trend to positively correlate with BMI, but not with glucose in female individuals [7]. Now, we reveal a relationship between circulating levels of ISM1 and obesity is investigated in a pubertal population. The motivation for focusing on the identification of new biomarkers in puberty lies in the fact that sexual maturation has been presented as a significant metabolic risk period for children with obesity [4], and indeed, we previously described the role of S100A4 in IR through a multi-omics approach in children, providing an interesting knowledge into the plausible molecular mechanism underlying that association [10]. Here, in a pubertal sample of 119 children, we show how higher levels of ISM1 in children with obesity compared to normal-weight and overweight, and a robust positive association between ISM1 serum levels and BMI Z-score in boys, indicating a putative sexual dimorphism. However, MPO was negatively associated with circulating levels of ISM1. Indeed, MPO is the most abundant protein in human neutrophils, playing a major role in inflammation, oxidative stress, lipoprotein oxidation, and atherosclerosis $[15,19]$. Moreover, MPO deficient mice are resistant to diet-induced obesity and IR, and inhibition of MPO activity in the neutrophils decreases dietinduced IR in obese mice, and activation of MPO is associated with the development of obesity and obesity-associated IR [20]. Group comparisons for ISM1 levels also revealed significant results in boys, although no significant changes were observed when comparing extreme experimental conditions in relation to IR (normal-weight vs. obese with IR). Jiang et al. (2021) [7] 200 determined that ISM1 signaling is dependent on PI3K and shares downstream phosphorylation 201 targets with insulin signaling, such as -AKT, p-AKT, p-ERK1/2 and p-S6. Outstandingly, ISM1 202 activates a PI3K-AKT signaling pathway independently of the insulin and insulin-like growth factor 2031 receptors, being most likely to signal through another, yet to be identified, receptor tyrosine 204 kinase. We found a correlation with obesity but not with HOMA-IR in children, which would point 
medRxiv preprint doi: https://doi.org/10.1101/2022.03.02.22271664; this version posted March 4, 2022. The copyright holder for this preprint (which was not certified by peer review) is the author/funder, who has granted medRxiv a license to display the preprint in perpetuity. It is made available under a CC-BY-NC-ND 4.0 International license .

to the adipokine ISM1 with a direct role in obesity but not in the metabolic status derived from IR. Remarkably, while the glucoregulatory function of the novel adipokine is shared with insulin, ISM1 also neutralizes lipid accumulation in the liver by inhibiting de novo lipogenesis, promoting protein synthesis and preventing hepatic steatosis in a diet-induced fatty liver mouse model. Nevertheless, in addition to a disturbed hepatic and postprandial lipoprotein metabolism, enhanced triacylglycerol lipolysis in adipocytes and subsequent fatty acid flux to the liver are major determinants of hepatic steatosis [21]. As insulin is a major anti-lipolytic hormone in adipocytes, therefore, it is plausible that ISM1 signaling indirectly modulates hepatic lipid accumulation by inhibiting fatty acid release from adipose tissue in mice (Heeren 2021a). Additionally, in the paper of Jiang et al. (2021) [7], the therapeutic dosing of recombinant ISM1 improves glucose tolerance to the same degree as metformin, enhances diabetes in diet-induced obese mice and ameliorates hepatic steatosis in a diet-induced fatty liver mouse model, establishing that the recombinant Ism1 and its derivatives may be explored for therapeutic purposes and may offer certain advantages over current monotherapies. Nonetheless, the observed higher circulating ISM1 levels in pubertal children suggest that maybe an ISM1 resistance is present, as administration of ISM1 into mice with established disease improves glucose and lipid dysfunction in the diet-induced obesity. Additionally, we should consider that pubertal children did not show hyperglycemia, which it might mask the observed effects of ISM1 in mice.

The strengths of our findings are the relatively high number of recruited children from different centers in the country (Andalucia, Galicia and Aragón); the novelty of the recently described new adipokine, which has not been reported elsewhere in humans, and the possibility to correlate with several plasma adipokines, inflammation, and cardiovascular risk biomarkers in the subcohort. Furthermore, the availability of DNA methylation analysis by using the Infinium MethylationEPIC microarray using bead chip technology in all the children population allowed us to observe twoenhancer related CpG sites of ISM1 (cg03304641 and cg14269097) associated with serum levels of ISM1 in children. As a limitation, though ISM1 serum levels are associated with BMI Z-score, we cannot distinguish the origin of the circulating levels simply because ISM1 is secreted by other non-adipose cells, and a secondary validation population would be needed to confirm these findings.

In conclusion, the circulating levels of the novel insulin-like adipokine ISM1 are significantly higher in pubertal children with obesity, and strongly associated with BMI Z-score in boys. Furthermore, we reveal two DNA methylations in two-enhancer-related CpG sites of the ISM1 region associated with serum levels of the protein in children with obesity. 
medRxiv preprint doi: https://doi.org/10.1101/2022.03.02.22271664; this version posted March 4, 2022. The copyright holder for this preprint (which was not certified by peer review) is the author/funder, who has granted medRxiv a license to display the preprint in perpetuity.

It is made available under a CC-BY-NC-ND 4.0 International license .

Conflicts of interest: The authors have no conflict of interests to disclose. No author received any form of payment to produce this paper.

Acknowledgements: The authors would like to thank the children and parents who participated in the study.

Funding source: This work was supported by the Plan Nacional de Investigación Científica, Desarrollo e Innovación Tecnológica $(I+D+I)$, Instituto de Salud Carlos III-Health Research Funding (FONDOS FEDER) (PI051968, PI1102042 and PI1600871); Redes temáticas de Investigación cooperativa RETIC (Red SAMID RD12/0026/0015) and the Mapfre Foundation.

Author contributions: $C A G$ is the guarantor of this work. AG and CAG contributed to the study concept of the cross-sectional study. FJRO, AAR and CAG design this study. RL, GB, MG, and LM participated in the child recruitment and anthropometric measures (data acquisition). CAG and AAR revised DNA extraction and methylation analyses. FJRO and MCR planned and performed the ISM1 analysis in serum of the children. AAR and FJRO performed all data analyses. AAR, FJRO and CAG took part in the interpretation of data. FJRO and CAG wrote the manuscript. All authors took park in the critical revision of the manuscript. CAG, RL and GB obtained funding. All authors approved the final version of the manuscript.

Abbreviations: IR, insulin resistance; WC, waist circumference; TNF- $\alpha$, tumour necrosis factor alpha; hsCRP, high-sensitivity CRP; IL, interleukin; PAI-1, total plasminogen activator inhibitor-1; MPO, myeloperoxidase; MCP-1, monocyte chemoattractant protein 1; MMP-9, matrix metalloproteinase-9; sICAM-1, soluble intercellular cell adhesion molecule-1; VCAM, soluble vascular cell adhesion molecule-1; MLR, multiple linear regression; FDR, false discovery rate; LME, linear mixed-effects; ISM1, isthmin-1; T2D, type 2 diabetes; MPO, myeloperoxidase.

\section{References}

1. Maffeis, C. and A. Morandi, Body composition and insulin resistance in children. European Journal of Clinical Nutrition, 2018. 72(9): p. 1239-1245.

2. Kelsey, M.M., et al., The Impact of Obesity On Insulin Sensitivity and Secretion During Pubertal Progression: A Longitudinal Study. The Journal of clinical endocrinology and metabolism, 2020. 105(5): p. e2061-e2068.

3. Reinehr, T., et al., Strong effect of pubertal status on metabolic health in obese children: $a$ longitudinal study. J Clin Endocrinol Metab, 2015. 100(1): p. 301-8. 
medRxiv preprint doi: https://doi.org/10.1101/2022.03.02.22271664; this version posted March 4, 2022. The copyright holder for this preprint (which was not certified by peer review) is the author/funder, who has granted medRxiv a license to display the preprint in perpetuity.

It is made available under a CC-BY-NC-ND 4.0 International license .

272 4. Reinehr, T. and C.L. Roth, Is there a causal relationship between obesity and puberty? Lancet Child Adolesc Health, 2019. 3(1): p. 44-54.

5. Luo, L. and M. Liu, Adipose tissue in control of metabolism. J Endocrinol, 2016. 231(3): p. R77r99.

6. Hannon, T.S., J. Janosky, and S.A. Arslanian, Longitudinal study of physiologic insulin resistance and metabolic changes of puberty. Pediatr Res, 2006. 60(6): p. 759-63.

7. Jiang, Z., et al., Isthmin-1 is an adipokine that promotes glucose uptake and improves glucose tolerance and hepatic steatosis. Cell Metab, 2021. 33(9): p. 1836-1852.e11.

8. Heeren, J. and L. Scheja, Isthmin 1 - a novel insulin-like adipokine. Nat Rev Endocrinol, 2021. 17(12): p. 709-710.

9. Pires, L.V., et al., The Vitamin D Decrease in Children with Obesity Is Associated with the Development of Insulin Resistance during Puberty: The PUBMEP Study. Nutrients, 2021. 13(12).

10. Anguita-Ruiz, A., et al., The protein S100A4 as a novel marker of insulin resistance in prepubertal and pubertal children with obesity. Metabolism, 2020. 105: p. 154187.

11. McCrindle, B.W., Assessment and management of hypertension in children and adolescents. Nat Rev Cardiol, 2010. 7(3): p. 155-63.

12. Anguita-Ruiz, A., et al., $X$ chromosome genetic data in a Spanish children cohort, dataset description and analysis pipeline. Sci Data, 2019. 6(1): p. 130.

13. Rupérez, A.I., et al., Cardiovascular risk biomarkers and metabolically unhealthy status in prepubertal children: Comparison of definitions. Nutr Metab Cardiovasc Dis, 2018. 28(5): p. 524530.

14. Ruiz-Ojeda, F.J., et al., Effects of X-chromosome Tenomodulin Genetic Variants on Obesity in a Children's Cohort and Implications of the Gene in Adipocyte Metabolism. Sci Rep, 2019. 9(1): p. 3979.

15. Gómez García, A., et al., Myeloperoxidase is associated with insulin resistance and inflammation in overweight subjects with first-degree relatives with type 2 diabetes mellitus. Diabetes Metab J, 2015. 39(1): p. 59-65.

16. Thomas, D. and C. Apovian, Macrophage functions in lean and obese adipose tissue. Metabolism: clinical and experimental, 2017. 72: p. 120-143.

17. Scheja, L. and J. Heeren, The endocrine function of adipose tissues in health and cardiometabolic disease. Nat Rev Endocrinol, 2019. 15(9): p. 507-524.

18. OsÓRio, L., X. Wu, and z. zhou, Distinct spatiotemporal expression of ISM1 during mouse and chick development. Cell Cycle, 2014. 13(10): p. 1571-1582.

19. Shao, B., S. Pennathur, and J.W. Heinecke, Myeloperoxidase targets apolipoprotein A-I, the major high density lipoprotein protein, for site-specific oxidation in human atherosclerotic lesions. The Journal of biological chemistry, 2012. 287(9): p. 6375-6386.

20. Wang, Q., et al., Myeloperoxidase deletion prevents high-fat diet-induced obesity and insulin resistance. Diabetes, 2014. 63(12): p. 4172-4185.

21. Heeren, J. and L. Scheja, Metabolic-associated fatty liver disease and lipoprotein metabolism. Mol Metab, 2021. 50: p. 101238. 
medRxiv preprint doi: https://doi.org/10.1101/2022.03.02.22271664; this version posted March 4, 2022. The copyright holder for this preprint (which was not certified by peer review) is the author/funder, who has granted medRxiv a license to display the preprint in perpetuity.

It is made available under a CC-BY-NC-ND 4.0 International license .

Table 1. Association between the change in ISM1 serum levels and the change in metabolic outcomes in boys in the cross-sectional population (PUBMEP study).

\begin{tabular}{|c|c|c|c|c|c|c|c|}
\hline Outcome & Beta & SE & Cl.LOW & Cl.HIGH & T-value & P-Value & FDR \\
\hline BMI Z-score & 0.356742 & 0.018365 & 0.017981 & 0.089973 & 2.939048 & $0.005009333^{*}$ & 0.1302427 \\
\hline MPO $(\mu \mathrm{g} / \mathrm{L})$ & -0.34989 & 2.845957 & -11.495421 & -0.339269 & -2.079211 & $0.043596686^{*}$ & 0.4932982 \\
\hline SBP & 0.262452 & 0.2514465 & -0.04712895 & 0.9385412 & $1,772,569$ & 0.08292251 & 0.4932982 \\
\hline AST (U/L) & 0.273129 & 0.066067 & -0.017778 & 0.241207 & 1.690916 & 0.097474922 & 0.4932982 \\
\hline $\operatorname{ALT}(\mathrm{U} / \mathrm{L})$ & 0.235236 & 0.113399 & -0.033886 & 0.410636 & 1.661178 & 0.103196554 & 0.4932982 \\
\hline $\mathrm{HsCRP}(\mathrm{mg} / \mathrm{L})$ & 0.234346 & 0.348906 & -0.128352 & 1.239357 & 1.592128 & 0.118205328 & 0.4932982 \\
\hline TAG (mg/dL) & 0.232391 & 0.404079 & -0.173903 & 1.410089 & 1.529632 & 0.132811041 & 0.4932982 \\
\hline Resistin ( $\mu \mathrm{g} / \mathrm{L})$ & 0.223976 & 0.104071 & -0.057597 & 0.350361 & 1.406563 & 0.165998677 & 0.5394957 \\
\hline slCAM1 (mg/L) & -0.208464 & 0.009806 & -0.031567 & 0.006874 & -1.259028 & 0.214108936 & 0.6185369 \\
\hline GGT (U/L) & 0.190581 & 0.104644 & -0.081142 & 0.329061 & 1.184585 & 0.242137353 & 0.6295571 \\
\hline DBP & 0.1500147 & 0.1634918 & -0.1569578 & 0.48393 & 0.9999652 & 0.3225587 & 0.6671418 \\
\hline MCP1 (ng/L) & 0.162466 & 0.694272 & -0.676507 & 2.045038 & 0.985587 & 0.329277816 & 0.6671418 \\
\hline TNFa (ng/L) & 0.14881 & 0.012211 & -0.012852 & 0.035016 & 0.907526 & 0.368662495 & 0.6671418 \\
\hline Leptin $(\mu \mathrm{g} / \mathrm{L})$ & 0.079798 & 0.057139 & -0.06128 & 0.162704 & 0.887529 & 0.379220108 & 0.6671418 \\
\hline IL6 (ng/L) & -0.18923 & 0.788794 & -2.241604 & 0.850468 & -0.881812 & 0.384889528 & 0.6671418 \\
\hline QUICKI & 0.122802 & 0.000445 & -0.00051 & 0.001233 & 0.813133 & 0.420075148 & 0.6826221 \\
\hline tPAl1 $(\mu \mathrm{g} / \mathrm{L})$ & -0.082656 & 0.165824 & -0.427502 & 0.222527 & -0.618051 & 0.539463347 & 0.7869461 \\
\hline P Selectine $(\mu \mathrm{g} / \mathrm{L})$ & -0.09031 & 0.292972 & -0.752906 & 0.395543 & -0.609894 & 0.544808842 & 0.7869461 \\
\hline HDL-c (mg/dL) & -0.054999 & 0.162272 & -0.382981 & 0.253125 & -0.400119 & 0.690881956 & 0.8600189 \\
\hline Hip Circumference $(\mathrm{cm})$ & -0.026917 & 0.09899 & -0.229915 & 0.158124 & -0.362617 & 0.718483164 & 0.8600189 \\
\hline IL8 (ng/L) & -0.056542 & 0.087295 & -0.200509 & 0.141689 & -0.336899 & 0.737662007 & 0.8600189 \\
\hline Insulin (mU/L) & -0.044402 & 0.117725 & -0.266814 & 0.194668 & -0.306415 & 0.760587143 & 0.8600189 \\
\hline HOMA-IR & -0.045483 & 0.026985 & -0.061153 & 0.04463 & -0.306152 & 0.760785993 & 0.8600189 \\
\hline Adiponectin (mg/L) & 0.021981 & 0.103484 & -0.186343 & 0.219314 & 0.159307 & 0.874095447 & 0.9469367 \\
\hline Glucose (mg/dL) & -0.001604 & 0.112144 & -0.221027 & 0.218578 & -0.010919 & 0.99133255 & 0.9913325 \\
\hline
\end{tabular}

319 Multiple regression analyses with the change in ISM1 serum levels as independent variable. 320 Models were adjusted for the change in BMI Z-Score, the origin, and the pubertal stage reached. 321 When the dependent variable was the change in the BMI Z-Score, we replaced the BMI 322 confounder with the change in Insulin levels. The change in Height was further included in models 323 when the dependent variable was change in Blood pressure. Abbreviations: SE, standard error; $324 \mathrm{Cl}$, confidence interval; AST, aspartate aminotransferase; ALT, alanine aminotransferase; BMI, 325 body mass index; WC, waist circumference; SBP, systolic blood pressure; DBP, diastolic blood 326 pressure; HOMA-IR, homeostasis model assessment for insulin resistance; QUICKI, quantitative 327 insulin sensitivity check index; TAG, triglycerides; HDL-c, high-density lipoproteins-cholesterol;; 328 hsCRP, high-sensitivity CRP; MCP-1,monocyte chemoattractant protein 1; GGT, 329 Gammaglutamyltransferase; TNF- $\alpha$, tumour necrosis factor alpha; TSH, thyroid-stimulating 330 hormone; IL, interleukin; PAI-1, plasminogen activator inhibitor-1; MPO, myeloperoxidase; 331 sICAM, soluble intercellular cell adhesion molecule-1. ${ }^{*} \mathrm{P}<0.05$.

333 Table 2. Association between the change in ISM1 serum levels and the change in metabolic outcomes in girls in the cross-sectional population (PUBMEP study).

\begin{tabular}{llllllll}
\hline Outcome & Beta & SE & CI.LOW & Cl.HIGH & T-value & P-Value & FDR \\
\hline HsCRP $(\mathrm{mg} / \mathrm{L})$ & -0.212532 & 0.275906 & -0.993822 & 0.087729 & -1.642031 & 0.10618814 & 0.9518221 \\
tPAl1 $(\mu \mathrm{g} / \mathrm{L})$ & -0.203555 & 0.222168 & -0.796221 & 0.074676 & -1.623874 & 0.109825622 & 0.9518221 \\
AST $(\mathrm{U} / \mathrm{L})$ & -0.161062 & 0.089849 & -0.2849 & 0.067309 & -1.210869 & 0.230856581 & 0.9591424 \\
BMI Z-score & 0.131089 & 0.024629 & -0.02142 & 0.075127 & 1.090312 & 0.280008946 & 0.9591424 \\
Adiponectin $(\mathrm{mg} / \mathrm{L})$ & -0.14196 & 0.115312 & -0.350002 & 0.102022 & -1.075251 & 0.286714995 & 0.9591424 \\
ALT $(\mathrm{U} / \mathrm{L})$ & -0.122581 & 0.084927 & -0.254045 & 0.07887 & -1.031329 & 0.306668253 & 0.9591424 \\
GGT $(\mathrm{U} / \mathrm{L})$ & -0.122033 & 0.068911 & -0.199177 & 0.070953 & -0.930365 & 0.35603822 & 0.9591424 \\
QUICKI & -0.091113 & 0.00047 & -0.001278 & 0.000563 & -0.760771 & 0.449823868 & 0.9591424 \\
HDL-c (mg/dL) & 0.094496 & 0.228087 & -0.278695 & 0.615407 & 0.738122 & 0.463416645 & 0.9591424 \\
HOMA-IR & 0.087244 & 0.034593 & -0.042877 & 0.092727 & 0.720527 & 0.474046011 & 0.9591424
\end{tabular}


medRxiv preprint doi: https://doi.org/10.1101/2022.03.02.22271664; this version posted March 4, 2022. The copyright holder for this preprint (which was not certified by peer review) is the author/funder, who has granted medRxiv a license to display the preprint in perpetuity. It is made available under a CC-BY-NC-ND 4.0 International license .

335

336

337

338

339

340

341

342

343

344

345

346

347

348

349

350

351

352

353

354

355

356

357

358

359

360

361

362
0.9591424
0.9591424
0.9591424
0.9591424
0.9591424
0.9591424
0.9591424
0.9591424
0.9591424
0.9591424
0.9591424
0.9591424
0.9591424
0.9591424
0.9591424

$\begin{array}{ll}0.525493807 & 0.9591424 \\ 0.533496578 & 0.9591424 \\ 0.4433014 & 0.9591424 \\ 0.617556761 & 0.9591424 \\ 0.651008589 & 0.9591424 \\ 0.666686377 & 0.9591424 \\ 0.731167604 & 0.9591424 \\ 0.796561463 & 0.9591424 \\ 0.802358281 & 0.9591424 \\ 0.7692668 & 0.9591424 \\ 0.884457754 & 0.9591424 \\ 0.885014516 & 0.9591424 \\ 0.939666438 & 0.9591424 \\ 0.955113059 & 0.9591424 \\ 0.959142396 & 0.9591424\end{array}$

Multiple regression analyses with the change in ISM1 serum levels as independent variable. Models were adjusted for the change in BMI Z-Score, the origin, and the pubertal stage reached. When the dependent variable was the change in the BMI Z-Score, we replaced the BMI confounder with the change in Insulin levels. The change in Height was further included in models when the dependent variable was change in Blood pressure. Abbreviations: SE, standard error; $\mathrm{Cl}$, confidence interval; AST, aspartate aminotransferase; $\mathrm{ALT}$, alanine aminotransferase; BMI, body mass index; WC, waist circumference; SBP, systolic blood pressure; DBP, diastolic blood pressure; HOMA-IR, homeostasis model assessment for insulin resistance; QUICKI, quantitative insulin sensitivity check index; TAG, triacylglycerols; HDL-c, high-density lipoproteins-cholesterol; hsCRP, high-sensitivity CRP; MCP-1,monocyte chemoattractant protein 1; GGT, Gammaglutamyltransferase; TNF- $\alpha$, tumour necrosis factor alpha; $\mathrm{TSH}$, thyroid-stimulating hormone; IL, interleukin; PAI-1, plasminogen activator inhibitor-1; MPO, myeloperoxidase; sICAM, soluble intercellular cell adhesion molecule-1. ${ }^{*} \mathrm{P}<0.05$.

\section{Figure legend}

Figure 1. Group comparisons for ISM1 serum levels $(\mathrm{ng} / \mathrm{mL})$ in the pubertal population of 119 children. A) Comparison between normal-weight, overweight and obese. B) Comparison between normal-weight non-IR, non-IR and IR in children. The two-way ANOVA, Tukey's multiple comparisons test was employed to assess group differences in ISM1 levels according to standard statistical assumptions. ${ }^{*} \mathrm{P}<0.05$

Figure 2. Multiple linear regressions analyses between the change in ISM1 serum levels (ng/mL) and the changes in BMI Z-score and leptin $(\mu \mathrm{g} / \mathrm{L})$ in the cross-sectional cohort. A reports the linear model with delta BMI Z-score as dependent variable, B refers to the model for delta leptin as dependent variable.

Figure 3. Multiple linear regressions analyses between the change in ISM1DNAmethylation status and ISM1 serum levels $(\mathrm{ng} / \mathrm{mL})$. A reports the linear model with delta ISM1 serum levels as dependent variable and cg03304641 as independent variable. B refers the linear model with delta ISM1 serum levels as dependent variable and cg14269097 as independent variable. 
medRxiv preprint doi: https://doi.org/10.1101/2022.03.02.22271664; this version posted March 4, 2022. The copyright holder for this preprint (which was not certified by peer review) is the author/funder, who has granted medRxiv a license to display the preprint in perpetuity. It is made available under a CC-BY-NC-ND 4.0 International license.

\section{Supplementary Figures}

364 Figure S1 related to Figure 2. Multiple linear regressions were employed with $M$ values as 365 independent variables and each outcome as the dependent variable. Models were adjusted for 366 confounders when necessary. Because percentage methylation is easily interpretable, beta 367 values were employed for the graphical representation of results. A refers to BMI Z-score as 368 dependent variable.

369 Figure S2 related to Figure 3. Cross-sectional associations between ISM1DNAmethylation 370 status and ISM1 serum levels $(\mathrm{ng} / \mathrm{mL})$. Multiple linear regressions were employed with $M$ values 371 as independent variables and each outcome as the dependent variable. Models were adjusted 372 for confounders when necessary. Because percentage methylation is easily interpretable, beta 373 values were employed for the graphical representation of results. 
medRxiv preprint doi: https://doi.org/10.1101/2022.03.02.22271664; this version posted March 4, 2022. The copyright holder for this preprint

Figure 1

A

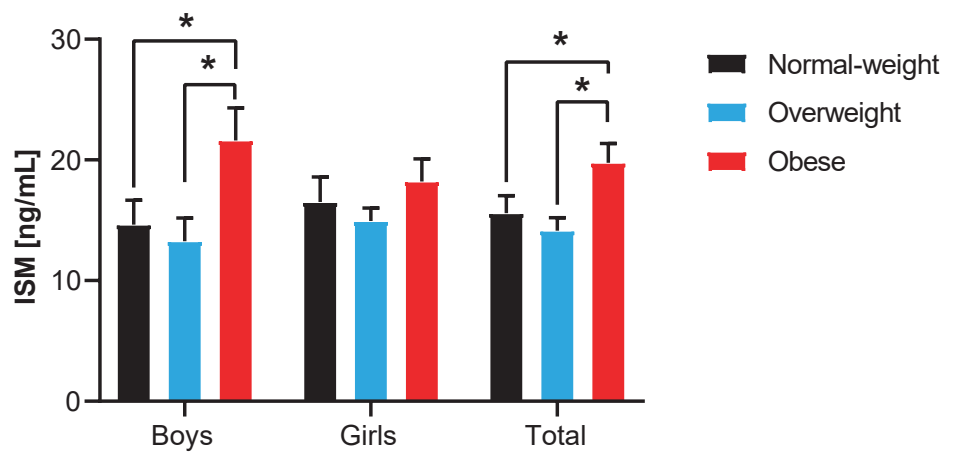

B

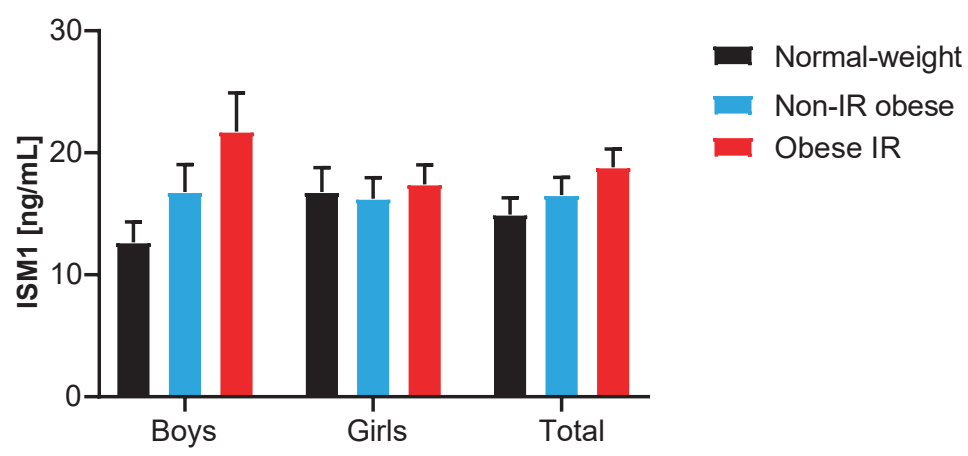


medRxiv preprint doi: https://doi.org/10.1101/2022.03.02.22271664; this version posted March 4, 2022. The copyright holder for this preprint (which was not certified by peer review) is the author/funder, who has granted medRxiv a license to display the preprint in perpetuity.

Figure 2

A Boys

Adj R2 $=0.3594$ Intercept $=1.8188$

Slope $=0.05397 \mathrm{P}=0.0050093$

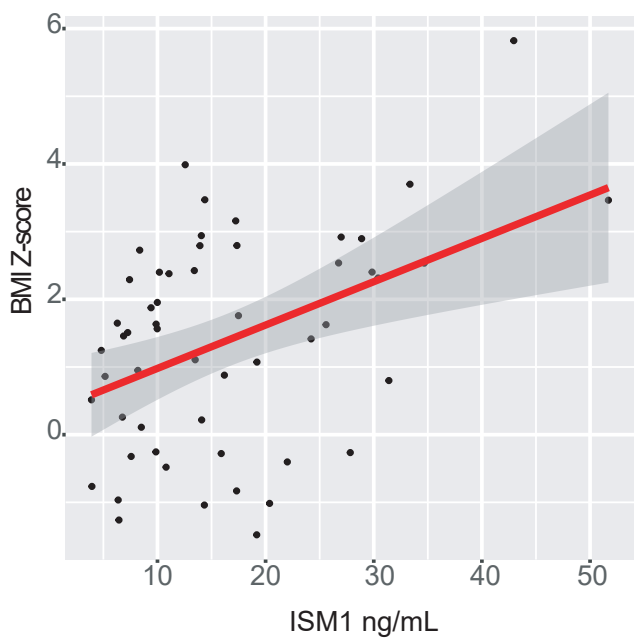

B

Boys

Adj R2 $=0.70119$ Intercept $=5.0192$

Slope $=0.050712 P=0.37922$

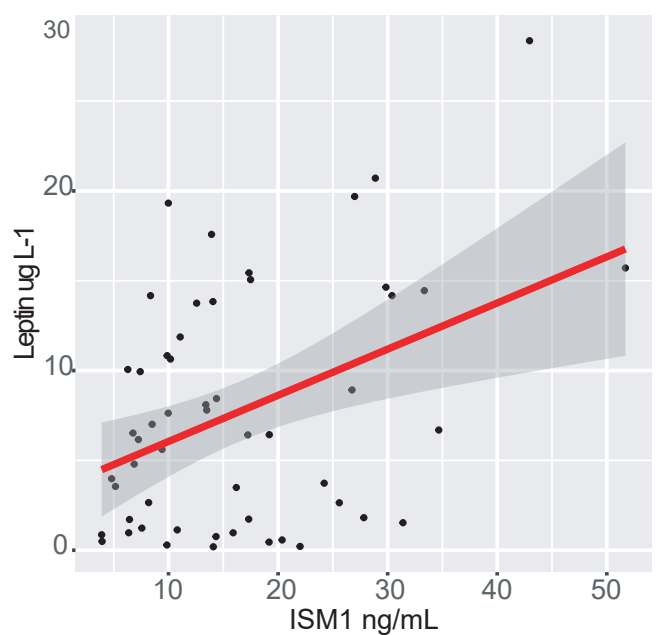

\section{Girls}

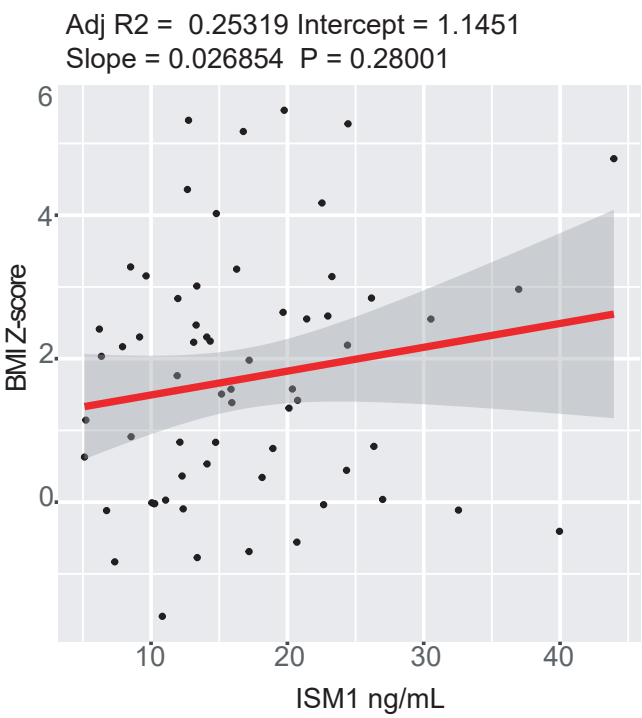

\section{Girls}

Adj R2 $=0.39142$ Intercept $=0.45633$

Slope $=0.030084 P=0.80236$

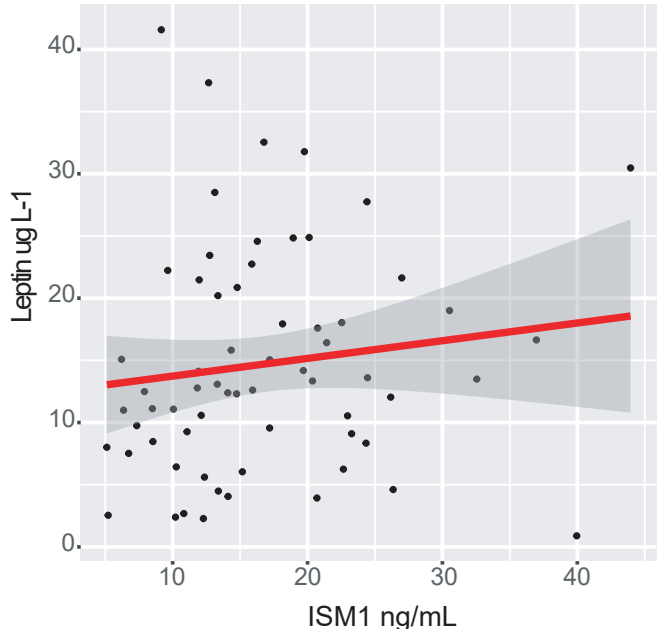


medRxiv preprint doi: https://doi.org/10.1101/2022.03.02.22271664; this version posted March 4, 2022. The copyright holder for this preprint (which was not certified by peer review) is the author/funder, who has granted medRxiv a license to display the preprint in perpetuity.

Figure S1 related to Fig. 2 It is made available under a CC-BY-NC-ND 4.0 International license .

A

\section{Boys}

$t$ student(52) $=3.37, p=0.001, \hat{r}$ pearson $=0.42$, Cl95\%[0.18,0.62], $\mathrm{n}=54$

6 .

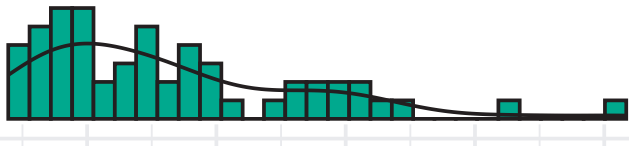

4.

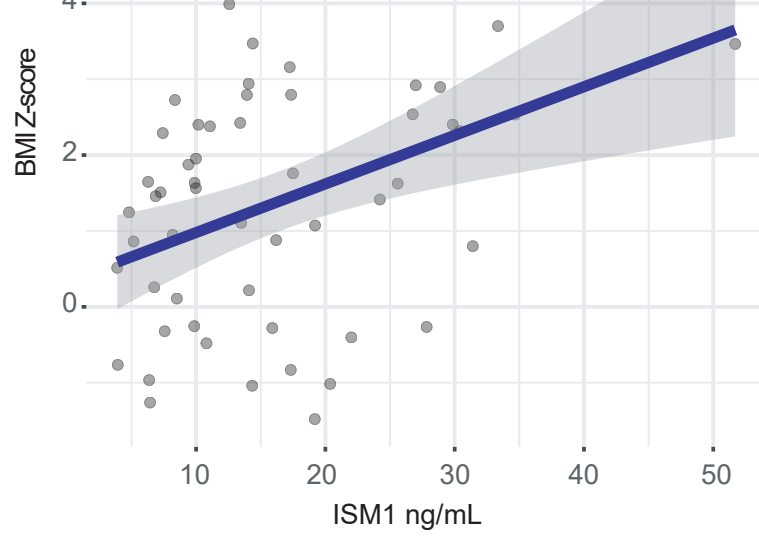

\section{Girls}

$t$ student(62) $=1.29, p=0.201, \hat{r}$ pearson $=0.16, C l 95 \%[-0.09,0.39], \mathrm{n}=64$

6

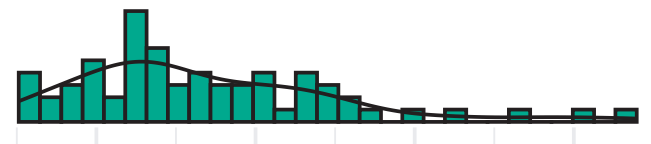

4.

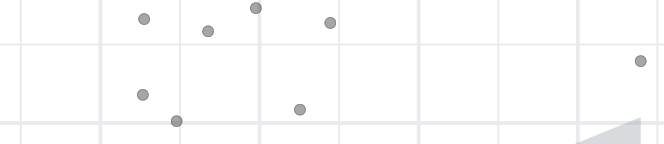

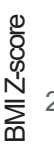

0.

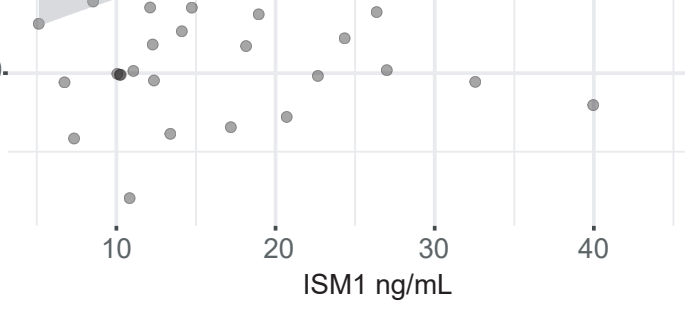

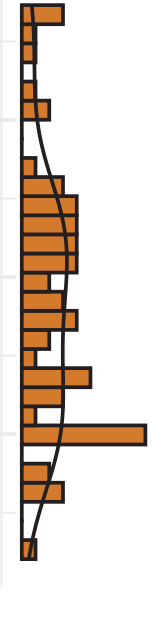


medRxiv preprint doi: https://doi.org/10.1101/2022.03.02.22271664; this version posted March 4, 2022. The copyright holder for this preprint (which was not certified by peer review) is the author/funder, who has granted medRxiv a license to display the preprint in perpetuity.

Figure 3

A

Adj R2 $=0.23393$ Intercept $=-17.588$ Slope $=3.2995$ $P=0.0062655$

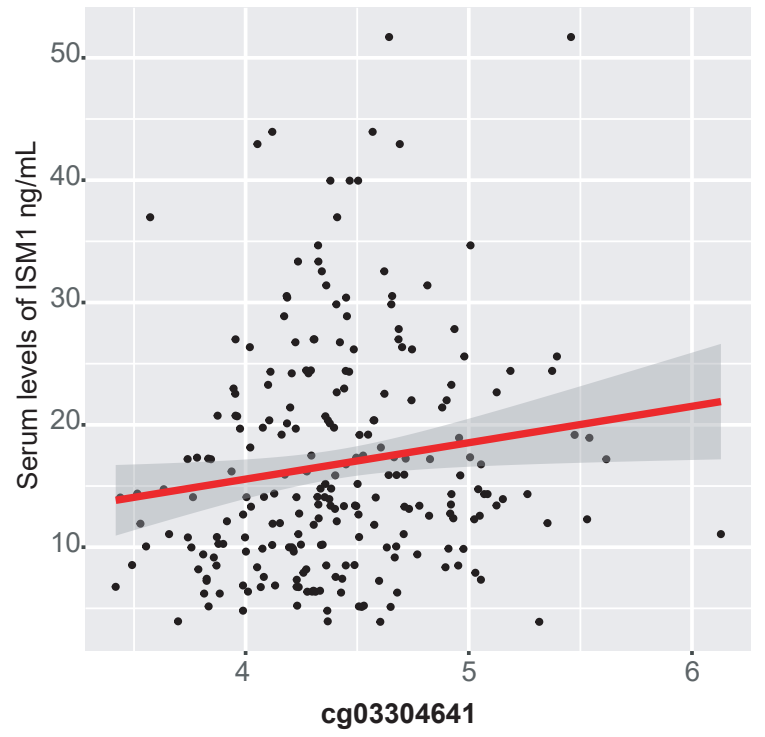

B

Adj R2 $=0.22329$ Intercept $=-7.1039$ Slope $=-3.665$ $P=0.038699$

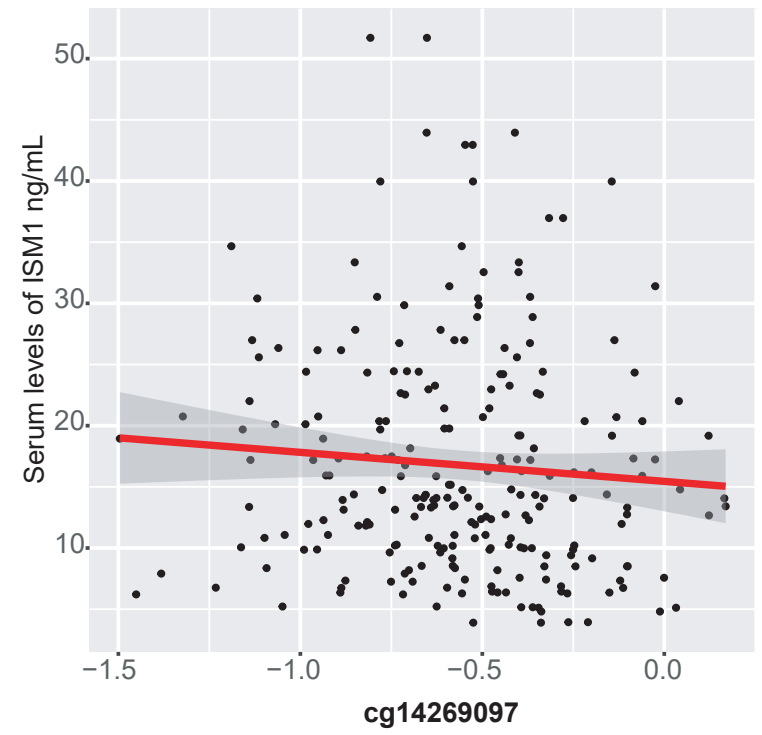


medRxiv preprint doi: https://doi.org/10.1101/2022.03.02.22271664; this version posted March 4, 2022. The copyright holder for this preprint (which was not certified by peer review) is the author/funder, who has granted medRxiv a license to display the preprint in perpetuity.

Figure $\mathrm{S} 2$ related to Fig. 3

A

$t$ student(236) $=1.21, p=0.228, \hat{r}_{p e a r s o n}=-0.08, C l 95 \%[-0.20,0.05], \mathrm{n}=238$

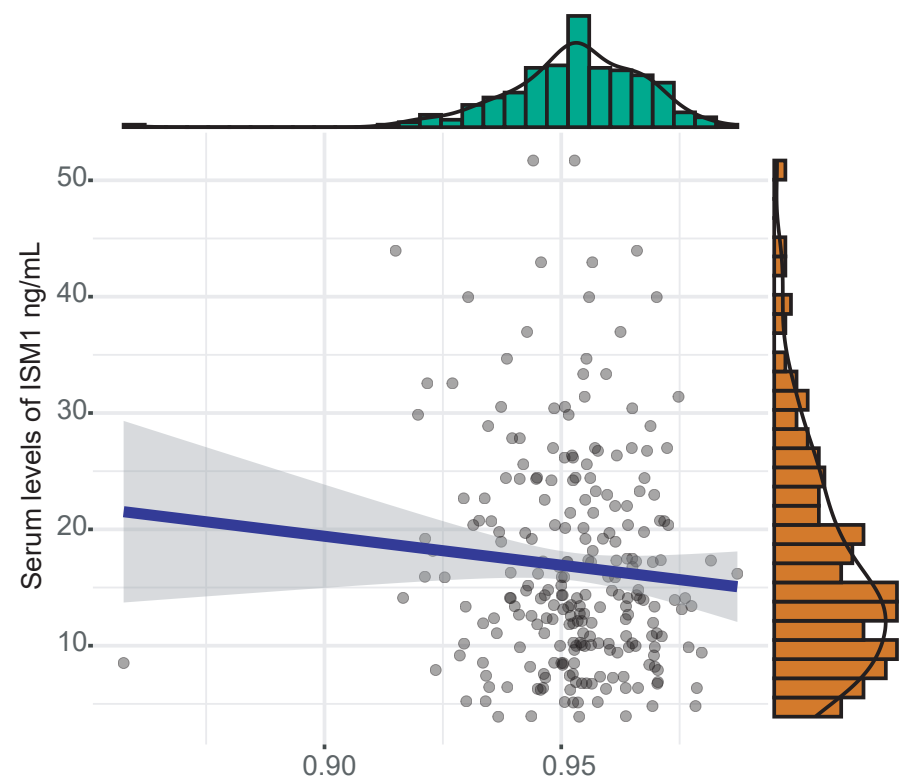

ISM1 beta levels (cg03304641)
B

$t$ student(236)=-1.18, $p=0.241$, rêarson $=-0.08$, Cl95\%[-0.20,0.05], $\mathrm{n}=238$

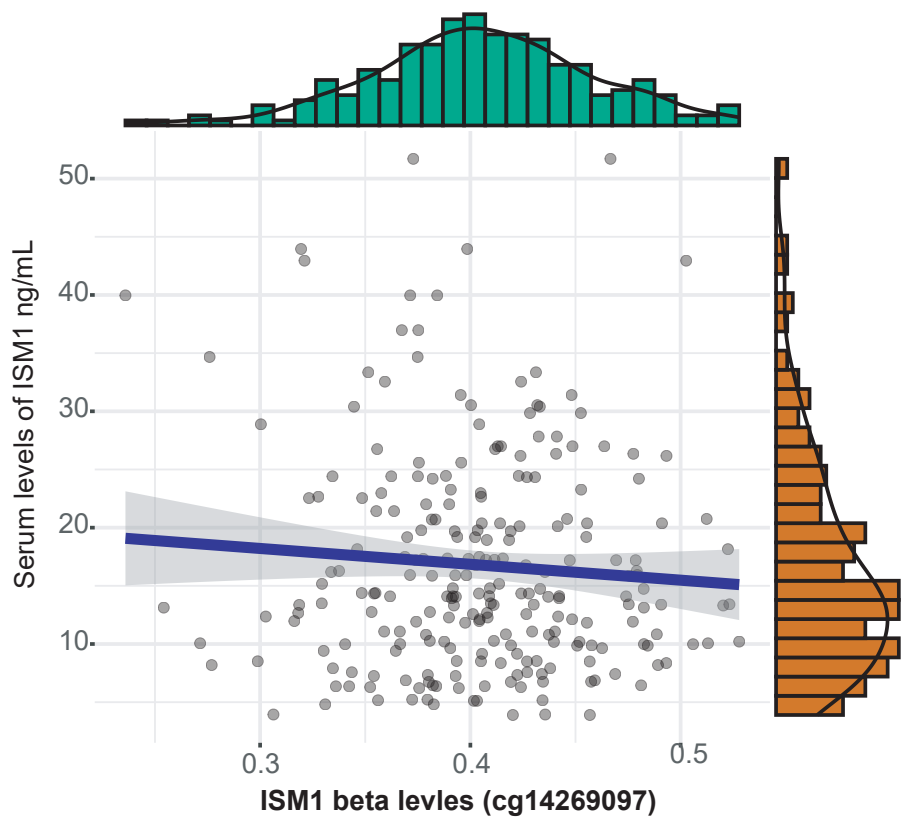


Supplementary table 1. General characteristics, anthropometry, biochemical parameters, adipokines and cardiovascular/pro-

inflammatory biomarkers in the cross-sectional cohort of 119 Spanish children.

\begin{tabular}{|c|c|c|c|c|}
\hline & Normal-weight & Overweight & Obese & P-Value \\
\hline Age & $14.87[11.22-17.59] \mathrm{NA}=0^{a}$ & $14.22[9.74-16.85] \mathrm{NA}=0^{a}$ & $14.33[9.72-18.07] \mathrm{NA}=0^{a}$ & 0.15170492 \\
\hline Sex & Girls=20; Boys $=17 \mathrm{NA}=0$ & Girls=19; Boys $=17 \mathrm{NA}=0$ & Girls=25; Boys $=20 \mathrm{NA}=0$ & 0.97257376 \\
\hline Glucose (mg/dL) & $85.11(9.03) \mathrm{NA}=0^{\mathrm{a}}$ & $85.33(6.76) \mathrm{NA}=0^{\mathrm{a}}$ & $85.2(8.71) \mathrm{NA}=0^{\mathrm{a}}$ & 0.78038444 \\
\hline TAG (mg/dL) & $63.25(27.5) \mathrm{NA}=1^{\mathrm{b}}$ & $66.69(31.29) \mathrm{NA}=0 \mathrm{ab}$ & $85.64(37.49) \mathrm{NA}=1^{\mathrm{a}}$ & 0.00101011 \\
\hline $\mathrm{HDLc}(\mathrm{mg} / \mathrm{dL})$ & $56.5[32-86] \mathrm{NA}=1^{\mathrm{a}}$ & $47[26-70] N A=0^{b}$ & $43[3-107] \mathrm{NA}=1^{\mathrm{b}}$ & $2.92 \mathrm{E}-06$ \\
\hline AST (U/L) & $22.36(3.82) N A=1^{a}$ & $20.94(6.27) \mathrm{NA}=0^{\mathrm{a}}$ & $22(5.64) \mathrm{NA}=1^{\mathrm{a}}$ & 0.15850533 \\
\hline $\operatorname{ALT}(\mathrm{U} / \mathrm{L})$ & $13.62(4.16) \mathrm{NA}=0^{\mathrm{b}}$ & $16.58(6.34) \mathrm{NA}=0^{\mathrm{ab}}$ & $21.11(8.61) \mathrm{NA}=0^{\mathrm{a}}$ & $1.22 \mathrm{E}-05$ \\
\hline GGT (U/L) & $11[6-27] N A=1^{a}$ & $13[1-27] N A=0$ ab & $15[2-44] N A=1^{b}$ & 0.00117436 \\
\hline Insulin (mU/L) & $8.73(3.52) \mathrm{NA}=0^{\mathrm{b}}$ & $12.58(6.13) \mathrm{NA}=0^{\mathrm{b}}$ & $21.08(11.52) \mathrm{NA}=0^{a}$ & $6.60 \mathrm{E}-09$ \\
\hline HsCRP (mg/L) & $0.63[0.2-30.1] \mathrm{NA}=2^{\mathrm{a}}$ & $1.78[0.2-18.4] \mathrm{NA}=2^{b}$ & $4.38[0.2-164.2] \mathrm{NA}=0^{b}$ & $2.89 \mathrm{E}-05$ \\
\hline Waist Hip ratio & $0.82[0.54-1.38] \mathrm{NA}=0^{a}$ & $0.83[0.74-1] \mathrm{NA}=1^{\mathrm{a}}$ & $0.93[0.75-2.11] \mathrm{NA}=1^{\mathrm{b}}$ & 8.42E-06 \\
\hline WC Height ratio & $0.43(0.05) \mathrm{NA}=0^{\mathrm{c}}$ & $0.52(0.05) \mathrm{NA}=1^{\mathrm{b}}$ & $0.61(0.08) N A=1^{a}$ & $1.47 \mathrm{E}-28$ \\
\hline QUICKI & $0.35[0.32-0.44] \mathrm{NA}=0^{a}$ & $0.34[0.29-0.39] \mathrm{NA}=0^{b}$ & $0.31[0.28-0.42] \mathrm{NA}=0^{c}$ & $7.70 \mathrm{E}-08$ \\
\hline $\mathrm{DBP}(\mathrm{mm} \mathrm{Hg})$ & 67.16 (12.49) NA=2 a & $67.93(8.11) \mathrm{NA}=2^{\mathrm{a}}$ & $70.44(11.51) \mathrm{NA}=1^{\mathrm{a}}$ & 0.29095778 \\
\hline $\mathrm{SBP}(\mathrm{mm} \mathrm{Hg})$ & $105.77(13.7) \mathrm{NA}=2^{\mathrm{b}}$ & $111.07(12.35) \mathrm{NA}=2 \mathrm{ab}$ & $116.7(15.42) \mathrm{NA}=1^{\mathrm{a}}$ & 0.01356016 \\
\hline Glucose (mmol/L) & $4.72(0.5) \mathrm{NA}=0^{\mathrm{a}}$ & $4.74(0.38) \mathrm{NA}=0^{\mathrm{a}}$ & $4.73(0.48) \mathrm{NA}=0^{\mathrm{a}}$ & 0.78038444 \\
\hline HOMA-IR & $1.84(0.78) \mathrm{NA}=0^{\mathrm{b}}$ & $2.69(1.44) N A=0^{b}$ & $4.53(2.71) \mathrm{NA}=0^{\mathrm{a}}$ & 5.38E-08 \\
\hline $\begin{array}{l}\text { Waist Circumference } \\
\left(\mathrm{cm}^{2}\right)\end{array}$ & 70.15 (7.99) NA=0 ${ }^{\circ}$ & $83.08(7.8) N A=1^{b}$ & $99.43(11.47) \mathrm{NA}=1^{\mathrm{a}}$ & $2.44 \mathrm{E}-25$ \\
\hline $\begin{array}{l}\text { Hip Circumference } \\
\left(\mathrm{cm}^{2}\right)\end{array}$ & $85.37(9.44) \mathrm{NA}=0^{\mathrm{c}}$ & $97.59(7.96) \mathrm{NA}=1^{\mathrm{b}}$ & $108.88(10.51) \mathrm{NA}=1^{\mathrm{a}}$ & $7.87 \mathrm{E}-18$ \\
\hline BMI Z-score & $-0.12[-1.59-0.78] \mathrm{NA}=0^{a}$ & $1.51[0.75-2.3] \mathrm{NA}=0^{\mathrm{b}}$ & $2.9[2.03-5.82] \mathrm{NA}=0^{\mathrm{C}}$ & $2.89 \mathrm{E}-22$ \\
\hline sICAM1 (mg/L) & $0.07[0.04-3.31] \mathrm{NA}=0^{\mathrm{a}}$ & $0.1[0.06-2.03] N A=0^{b}$ & $0.1[0.06-1.72] N A=0^{b}$ & 0.00219134 \\
\hline $\mathrm{MPO}(\mu \mathrm{g} / \mathrm{L})$ & $23.5[0.8-196.36] \mathrm{NA}=8^{\mathrm{a}}$ & $\begin{array}{l}33.63[0.88-1077.71] \mathrm{NA}=3 \\
\mathrm{a}\end{array}$ & $32.47[0.2-744.47] \mathrm{NA}=2^{\mathrm{a}}$ & 0.31811663 \\
\hline P Selectin $(\mu \mathrm{g} / \mathrm{L})$ & $42.17(12.27) \mathrm{NA}=0^{\mathrm{b}}$ & $47.1(15.59) \mathrm{NA}=0 \mathrm{ab}$ & $56.13(20.87) N A=1$ a & 0.00630924 \\
\hline Adiponectin (mg/L) & $13.47(8.58) \mathrm{NA}=0^{\mathrm{a}}$ & $12.57(7.62) \mathrm{NA}=0^{\mathrm{a}}$ & $8.35(5.26) N A=0^{b}$ & 0.00722112 \\
\hline Resistin $(\mu \mathrm{g} / \mathrm{L})$ & $18.12[9.19-44.31] \mathrm{NA}=0^{a}$ & $18.97[7.82-56.01] \mathrm{NA}=0^{a}$ & $21.18[10.91-77.23] \mathrm{NA}=0^{a}$ & 0.07726358 \\
\hline tPAl1 $(\mu \mathrm{g} / \mathrm{L})$ & $8.95(9.75) \mathrm{NA}=0^{\mathrm{b}}$ & $16.67(11.35) \mathrm{NA}=0^{\mathrm{b}}$ & 25.25 (14.54) NA=0 a & $1.40 \mathrm{E}-06$ \\
\hline
\end{tabular}




\begin{tabular}{|c|c|c|c|c|}
\hline IL6 (ng/L) & $8.28[0.16-173.01] \mathrm{NA}=9 \mathrm{a}^{\mathrm{a}}$ & $2.89[0.03-223.84] \mathrm{NA}=17^{\mathrm{a}}$ & $3.67[0.12-178.99] \mathrm{NA}=8^{a}$ & 0.14984527 \\
\hline IL8 (ng/L) & $2.58[0.56-27.33] \mathrm{NA}=0^{\mathrm{a}}$ & $2.01[0.27-30.27] \mathrm{NA}=0^{a}$ & $2.29[0.13-22.8] \mathrm{NA}=0^{\mathrm{a}}$ & 0.37108233 \\
\hline MCP1 (ng/L) & $110.82(39.87) \mathrm{NA}=0^{\mathrm{a}}$ & $100.26(48.49) \mathrm{NA}=0^{\mathrm{a}}$ & 107.32 (39.99) $\mathrm{NA}=0^{\mathrm{a}}$ & 0.55119851 \\
\hline TNFa (ng/L) & $2.73(0.76) \mathrm{NA}=0^{\mathrm{a}}$ & $2.57(1.02) \mathrm{NA}=0^{\mathrm{a}}$ & $2.66(0.78) \mathrm{NA}=0^{\mathrm{a}}$ & 0.71217629 \\
\hline Leptin (ng/L) & $3.93[0.19-21.63] \mathrm{NA}=0^{\mathrm{a}}$ & $10.7[1.53-41.58] \mathrm{NA}=0^{\mathrm{b}}$ & $14.64[6.42-37.32] \mathrm{NA}=0^{c}$ & $2.87 \mathrm{E}-10$ \\
\hline ISM1 (ng/mL) & $12.36[3.9-32.55] \mathrm{NA}=0^{\mathrm{a}}$ & $13.79[4.81-31.4] \mathrm{NA}=0^{\mathrm{a}}$ & $16.77[6.21-51.7] \mathrm{NA}=0^{\mathrm{a}}$ & 0.06447697 \\
\hline
\end{tabular}

4 Data are expressed as mean (standard deviation) or median [min-max] if not normally distributed. One-way ANOVA, Kruskal-Wallis and the Welch test were employed to assess group differences. Distributions within the same row with unlike superscript letters were significantly different $(p<0.05)$ according to Pairwise-t-tests, pairwise Mann-Whitney U-tests and Dunn tests. Childhood obesity was defined according to Cole et al. (2000). Abbreviations: ALR, adiponectin leptin ratio; Apo B, apolipoprotein B; Apo A, apolipoprotein A; $\mathrm{BMI}$, body mass index; DBP, diastolic blood pressure; HC, hip circumference; HDL-c, high-density lipoproteins-cholesterol; HOMA-IR, homeostasis model assessment for insulin resistance; hsCRP, high-sensitivity $\mathrm{C}$ reactive protein; IL, interleukin; IR, insulin resistance; ISM1, isthmin-1; LDL-c, low-density lipoproteins-cholesterol; MCP-1, monocyte chemoattractant protein 1; MPO, myeloperoxidase; $\mathrm{OB}$, obesity; PAI-1, plasminogen activator inhibitor-1; QUICKI, quantitative insulin sensitivity check index; SBP, systolic blood pressure; sICAM, soluble intercellular cell adhesion molecule-1; TAG, triacylglycerols; THS; Thyroid-Stimulating Hormone; TNF- $\alpha$, tumour necrosis factor alpha; WC, waist circumference. NA: non-available value. 
Supplementary table 2. List of Mapped CpG sites in the ISM1 domain.

\begin{tabular}{|c|c|c|c|c|c|c|c|c|c|c|c|}
\hline chr & pos & strand & CpG name & Probe_rs & Probe_maf & $\begin{array}{c}\text { UCSC_Ref } \\
\text { Gene_Grou } \\
\bar{p}\end{array}$ & $\begin{array}{l}\text { DNase_Hypersen } \\
\text { sitivity_NAME }\end{array}$ & $\begin{array}{c}\text { DNase_Hyper } \\
\text { sensitivity_E } \\
\text { vidence_Cou } \\
\text { nt }\end{array}$ & TFBS_NAME & $\begin{array}{c}\text { TFBS_E } \\
\text { vidence } \\
\text { Count }\end{array}$ & $\begin{array}{c}\text { Methyl450 } \\
\text { _Loci }\end{array}$ \\
\hline chr20 & 13200939 & + & cg25796439 & NA & NA & TSS1500 & $\begin{array}{c}\text { chr20:13200665- } \\
13201130 \\
\text { chr20:13200665- }\end{array}$ & 3 & & & TRUE \\
\hline chr20 & 13200992 & + & cg21561970 & NA & NA & TSS1500 & $\begin{array}{c}13201130 \\
\text { chr20:13201440- }\end{array}$ & 3 & & & TRUE \\
\hline chr20 & 13201650 & + & cg15015034 & $\begin{array}{c}\text { NA } \\
\text { rs3590730 }\end{array}$ & NA & TSS1500 & $\begin{array}{c}13201875 \\
\text { chr20:13201165- }\end{array}$ & 3 & & & TRUE \\
\hline chr20 & 13201214 & + & cg11155707 & 5 & 0,297039 & TSS1500 & 13201435 & 3 & & & TRUE \\
\hline chr20 & 13201655 & + & cg03172651 & NA & NA & TSS1500 & $\begin{array}{c}\text { chr20:13201440- } \\
13201875 \\
\text { chr20:13200665- }\end{array}$ & 3 & & & TRUE \\
\hline chr20 & 13200982 & + & cg26322248 & $\begin{array}{c}\text { NA } \\
\text { rs3590730 }\end{array}$ & NA & TSS1500 & $\begin{array}{c}13201130 \\
\text { chr20:13201165- }\end{array}$ & 3 & & & TRUE \\
\hline chr20 & 13201225 & + & $\operatorname{cg} 03725761$ & 5 & 0,297039 & TSS1500 & $\begin{array}{c}13201435 \\
\text { chr20:13201440- }\end{array}$ & 3 & & & TRUE \\
\hline chr20 & 13201662 & + & cg27427234 & NA & NA & TSS1500 & $\begin{array}{c}13201875 \\
\text { chr20:13202025- }\end{array}$ & 3 & & & TRUE \\
\hline chr20 & 13202437 & + & cg10378364 & NA & NA & 1stExon & $\begin{array}{c}13202550 \\
\text { chr20:13200665- }\end{array}$ & 3 & & & TRUE \\
\hline chr20 & 13200944 & + & cg14060111 & NA & NA & TSS1500 & $\begin{array}{c}13201130 \\
\text { chr20:13202025- }\end{array}$ & 3 & & & TRUE \\
\hline chr20 & 13202476 & - & cg04920227 & NA & NA & 1stExon & 13202550 & 3 & chr20:132794 & & TRUE \\
\hline chr20 & 13280130 & + & cg02962406 & NA & NA & 3'UTR & chr20:13200665- & & $40-13280456$ & 3 & TRUE \\
\hline chr20 & 13200973 & + & cg06262436 & NA & NA & TSS1500 & $\begin{array}{c}13201130 \\
\text { chr20:13201165- }\end{array}$ & 3 & & & TRUE \\
\hline chr20 & 13201342 & + & cg23504092 & NA & NA & TSS1500 & 13201435 & 3 & chr20:132794 & & TRUE \\
\hline chr20 & 13280201 & + & cg19727767 & $\begin{array}{c}\text { NA } \\
\text { rs7133029 }\end{array}$ & NA & 3'UTR & chr20:13201440- & & $40-13280456$ & 3 & TRUE \\
\hline chr20 & 13201844 & - & cg12741255 & 3 & 0,296533 & TSS1500 & $\begin{array}{c}13201875 \\
\text { chr20:13200665- }\end{array}$ & 3 & & & TRUE \\
\hline chr20 & 13200954 & + & cg12664209 & NA & NA & TSS1500 & $\begin{array}{c}13201130 \\
\text { chr20:13201165- }\end{array}$ & 3 & & & TRUE \\
\hline chr20 & 13201328 & + & cg15577927 & NA & NA & TSS1500 & $\begin{array}{c}13201435 \\
\text { chr20:13202025- }\end{array}$ & 3 & & & TRUE \\
\hline chr20 & 13202222 & + & cg20770339 & NA & NA & TSS200 & $\begin{array}{c}13202550 \\
\text { chr20:13200665- }\end{array}$ & 3 & & & TRUE \\
\hline chr20 & 13200969 & + & cg02145932 & $\begin{array}{c}\text { NA } \\
\text { rs7133029 }\end{array}$ & NA & TSS1500 & $\begin{array}{c}13201130 \\
\text { chr20:13201440- }\end{array}$ & 3 & & & TRUE \\
\hline chr20 & 13201829 & - & cg25178765 & 3 & 0,296533 & TSS1500 & 13201875 & 3 & & & TRUE \\
\hline
\end{tabular}




\begin{tabular}{|c|c|c|c|c|c|c|c|c|c|c|c|}
\hline chr20 & 13202225 & + & cg20081364 & NA & NA & TSS200 & $\begin{array}{c}\text { chr20:13202025- } \\
13202550 \\
\text { chr20:13201440- }\end{array}$ & 3 & & & TRUE \\
\hline chr20 & 13201551 & + & cg06567525 & NA & NA & TSS1500 & $\begin{array}{c}13201875 \\
\text { chr20:13200665- }\end{array}$ & 3 & & & TRUE \\
\hline chr20 & 13200980 & + & cg09491991 & NA & NA & TSS1500 & $\begin{array}{c}13201130 \\
\text { chr20:13200665- }\end{array}$ & 3 & & & TRUE \\
\hline $\begin{array}{l}\text { chr20 } \\
\text { chr20 }\end{array}$ & $\begin{array}{l}13200931 \\
13253578\end{array}$ & + & $\begin{array}{l}\text { cg04432319 } \\
\text { cg11466857 }\end{array}$ & $\begin{array}{l}\text { NA } \\
\text { NA }\end{array}$ & $\begin{array}{l}\text { NA } \\
\text { NA }\end{array}$ & $\begin{array}{l}\text { TSS1500 } \\
\text { Body }\end{array}$ & 13201130 & 3 & & & TRUE \\
\hline chr20 & 13246774 & - & cg22470917 & rs7269783 & 0,059433 & Body & $\begin{array}{c}\text { chr20:13246645- } \\
13246895 \\
\text { chr20:13251840- }\end{array}$ & 3 & & & \\
\hline chr20 & 13251901 & - & cg04049812 & NA & NA & Body & $\begin{array}{c}13252255 \\
\text { chr20:13227965- }\end{array}$ & 3 & & & \\
\hline chr20 & 13228392 & + & cg01440309 & NA & NA & Body & $\begin{array}{c}13228730 \\
\text { chr20:13202025- }\end{array}$ & 3 & & & \\
\hline $\begin{array}{l}\text { chr20 } \\
\text { chr20 }\end{array}$ & $\begin{array}{l}13202489 \\
13203343\end{array}$ & $\begin{array}{l}- \\
+\end{array}$ & $\begin{array}{l}\text { cg06355010 } \\
\text { cg12235430 }\end{array}$ & $\begin{array}{c}\text { NA } \\
\text { NA } \\
\text { rs } 1404565\end{array}$ & $\begin{array}{l}\text { NA } \\
\text { NA }\end{array}$ & $\begin{array}{l}\text { 1stExon } \\
\text { Body }\end{array}$ & 13202550 & 3 & & & TRUE \\
\hline chr20 & 13226652 & - & cg21903043 & 70 & 0,0133 & Body & & & chr20:132794 & & \\
\hline chr20 & 13280181 & + & cg16294620 & NA & NA & 3'UTR & chr20:13243460- & & $40-13280456$ & 3 & TRUE \\
\hline chr20 & 13243701 & - & cg02885188 & NA & NA & Body & $\begin{array}{c}13243955 \\
\text { chr20:13211665- }\end{array}$ & 3 & & & \\
\hline chr20 & 13211902 & + & cg14269097 & NA & NA & Body & $\begin{array}{c}13211950 \\
\text { chr20:13226080- }\end{array}$ & 3 & & & \\
\hline chr20 & 13226121 & - & cg18950540 & NA & NA & Body & $\begin{array}{c}13226250 \\
\text { chr20:13201440- }\end{array}$ & 3 & & & \\
\hline chr20 & 13201670 & + & cg03623378 & NA & NA & TSS1500 & $\begin{array}{c}13201875 \\
\text { chr20:13201165- }\end{array}$ & 3 & & & TRUE \\
\hline chr20 & 13201353 & + & cg19118558 & NA & NA & TSS1500 & 13201435 & 3 & chr20:132794 & & TRUE \\
\hline chr20 & 13279847 & + & cg25787377 & NA & NA & Body & & & $\begin{array}{l}40-13280456 \\
\text { chr20:132794 }\end{array}$ & 3 & TRUE \\
\hline chr20 & 13279946 & + & cg19647607 & NA & NA & Body & chr20:13243460- & & $40-13280456$ & 3 & TRUE \\
\hline chr20 & 13243555 & - & cg24256058 & NA & NA & Body & 13243955 & 3 & chr20:132794 & & \\
\hline chr20 & 13279761 & + & cg20777315 & NA & NA & Body & chr20:13277725- & & $40-13280456$ & 3 & TRUE \\
\hline $\begin{array}{l}\text { chr20 } \\
\text { chr20 }\end{array}$ & $\begin{array}{l}13277967 \\
13205832\end{array}$ & $\begin{array}{l}+ \\
+\end{array}$ & $\begin{array}{l}\text { cg24488317 } \\
\text { cg25411902 }\end{array}$ & $\begin{array}{c}\text { NA } \\
\text { NA } \\
\text { rs } 1112843\end{array}$ & $\begin{array}{l}\text { NA } \\
\text { NA }\end{array}$ & $\begin{array}{l}\text { Body } \\
\text { Body }\end{array}$ & 13278235 & 3 & & & $\begin{array}{l}\text { TRUE } \\
\text { TRUE }\end{array}$ \\
\hline chr20 & 13227047 & + & cg03304641 & 24 & 0,035224 & Body & chr20:13261540- & & & & \\
\hline chr20 & 13261553 & + & $\operatorname{cg} 13735403$ & NA & NA & Body & $\begin{array}{c}13261770 \\
\text { chr20:13201165- }\end{array}$ & 3 & & & \\
\hline chr20 & 13201349 & + & cg25384906 & NA & NA & TSS1500 & 13201435 & 3 & & & TRUE \\
\hline
\end{tabular}




\begin{tabular}{|c|c|c|c|c|c|c|c|c|c|}
\hline chr20 & 13201205 & - & cg19938101 & $\begin{array}{c}\text { rs3450233 } \\
5 \\
\text { rs3590730 }\end{array}$ & 0,000455 & TSS1500 & $\begin{array}{c}\text { chr20:13201165- } \\
13201435 \\
\text { chr20:13201165- }\end{array}$ & 3 & TRUE \\
\hline chr20 & 13201216 & + & cg25606624 & $\begin{array}{c}5 \\
\text { rs3450233 }\end{array}$ & 0,297039 & TSS1500 & $\begin{array}{c}13201435 \\
\text { chr20:13201165- }\end{array}$ & 3 & TRUE \\
\hline chr20 & 13201193 & - & $\operatorname{cg} 12448198$ & 5 & 0,000455 & TSS1500 & $\begin{array}{c}13201435 \\
\text { chr20:13267320- }\end{array}$ & 3 & TRUE \\
\hline chr20 & 13267421 & + & cg09495909 & NA & NA & Body & 13267535 & 3 & \\
\hline
\end{tabular}

